\title{
Питання психології
}

УДК 159.9.019.4:001.8(045)

DOI: $10.33099 / 2617-6858-20-58-5-138-145$

Остафійчук Р. Ю. аспірант,

НУ «Львівська політехніка»

https://orcid.org/0000-0003-2696-0491

\section{ЕМОЦІЙНИЙ ІНТЕЛЕКТ ЯК ЧИННИК КОНКУРЕНТОСПРОМОЖНОСТІ ПРАЦІВНИКІВ БАНКІВСЬКОЇ УСТАНОВИ}

У статті здійснено теоретичний аналіз основних підходів до вивчення поняття конкурентоспроможності. Розглянуто поняття емоційного інтелекту та його вплив на конкурентоспроможності працівника фінансово-кредитної установи. Визначені чинники, які здійснюють вплив на конкурентоспроможність працівників. Обтрунтована необхідність зацікавлення керівництва у створенні здорових конкурентних стосунків між працівниками, так як це забезпечує ефективність діяльності персоналу та успішність організації.

Ключові слова: конкуренція; конкурентоспроможність; емоційний інтелект; соціальний інтелект; емпатія.

Вступ. Враховуючи кількість існуючих на споживчому ринку фінансово-кредитних установ, перед банкірами постає проблема: організувати роботу свого підприємства так, щоб бути більш конкурентоспроможними. Це проявляється в обсязі та якості надання банківських послуг, осучасненні та опитимізації роботи, залучені зовнішніх та збереженні наявних клієнтів та ін.

Для ефективного функціонування організації, яка працює з людьми, важливим $є$ ступінь розвитку персоналу. Тому сучасному підприємству необхідно приділяти велике значення проблемам підбору кандидатів на вакантну посаду, а згодом управлінню i розвитку персоналу.

Бути конкурентоспроможним для працівника, означає здобувати кар'єрний ріст, отримувати кращу заробітну плату та різні види мотивації, мати визнання серед колег та адміністрації банку та бути більш корисним для організації. Тому необхідно створювати конкурентне середовище для працівників, де б кожен мав можливість реалізувати свій потенціал для позитивного особистісного результату та успіху банківської установи в цілому.

На сьогодні є вивчене поняття конкуренції та конкурентоздатності, визначено основні психологічні стратегії конкуренції в організаціях, досліджена проблема конкурентоздатноссті особистості. Менш вивченим $\epsilon$ емоційний інтелект як чинник конкурентоспроможності працівників організації, зокрема фінансово-кредитної.

Метою статті $\epsilon$ теоретичний аналіз проблеми емоційного інтелекту як чинника конкурентоспроможності працівників банківської установи.

Завданнями статті $€$ здійснити теоретичний аналіз наукових джерел 3 даної теми та проаналізувати теоретичні підходи до визначення поняття конкурентоспроможності та емоційного інтелекту.

Теоретиичне підгрунтя. У сучасній науці поняття «конкурентоспроможність» досліджується в психології, педагогіці, економіці, менеджменті та ін. У психології визначення цього поняття давали такі дослідники: щодо конкуренції i конкурентоспроможності (В.I. Андрєєв, Л.М. Карамушка, В.В. Корсакевич, О.А. Філь, Г.Д. Приказка, I.C. Бігун та інші), стратегій конкуренції в організаціях (Л.М. Карамушка, О.А. Філь, А. Шмельов).

Ідея емоційного інтелекту виходить із поняття соціального інтелекту, яке досліджували Е. Торндайк, Г. Айзенк, Дж. Гілфорд. Ця проблема сьогодні грунтується на наукових положеннях Д. Гоулмен, Н. Холл, Дж. Мейер, П. Селовей, Д. Карузо, С. Дерев'янко, С. Колот та ін.

Методологія i методи. Дослідження емоційного інтелекту як чинника конкурентоспроможності працівників банківської установи стає можливим завдяки 


\section{Питання психології}

синтезу наукових підходів, які взаємодоповнюють уявлення щодо поняття конкуренції, конкурентоспроможності, чинників зокрема емоційного інтелекту, його вплив на благополуччя працівника та організації.

Результати і обговорення. У найбільш загальному значенні конкурентоспроможність (від англ.. competitiveness конкурентоздатність, конкурентність, змагальність) розуміють як здатність певного суб'єкта (або об'єкта - якщо йдеться про товар) перевершити конкурентів в умовах наявного ринку. Результатом конкурентоспроможності $€$ фінансова/ маркетингова /організаційна перемога над конкурентами: наприклад, домінування на ринку внаслідок пропозиції кращого (якіснішого, дешевшого) товару, адекватнішого обслуговування клієнта, швидшої доставки тощо. Слід наголосити, що поняття конкурентоспроможності має сенс лише в умовах конкуренції та ринкової економіки. Тому існує наукова традиція аналізувати конкурентоспроможність групи чи особи в контексті конкурентних відносин на ринку [12].

Зокрема, С.А. Подосинніков вважає, що конкурентоспроможність - це складна інтегральна властивість особистості, яка характерна для людей, які готові брати участь у конкурентних відносинах у різних сферах діяльності, враховуючи свої індивідуальні здібності [11].

Л.М. Мітіна дає визначення поняттю конкурентоспроможності, що означає здатність вдосконалювати власні можливості для реалізації особистісного, морального, соціального чи професійного потенціалу. Автор вважала, що для розвитку конкурентоспроможної особистості необхідно розвивати іiі рефлексивність, здатність у динамічних обставинах правильно організувати свою діяльність і поведінку, розвивати в собі нові стилі мислення та володіти нетрадиційними підходами до вирішення проблем та адекватно реагувати в нетипових ситуаціях [10].

Отже, конкурентоспроможністю можна назвати соціально орієнтовану систему здібностей, властивостей і якостей особистості, яка характеризує іï потенційні можливості у досягненні успіху у різноманітних сферах життєдіяльності, при цьому забезпечує впевненість у собі, внутрішню гармонію та позитивне ставлення до світу.

Для розуміння поняття конкурентоспроможності важливо виділити якості, характерні для особистості, здатної до конкуренції.

В. I. Андрєєв виділяє такі якості конкурентоспроможності особистості: чіткість встановлених цілей та ціннісних орієнтацій, любов до праці, творчий i креативний підхід до роботи, здатність ризикувати, незалежність, розвинені лідерські якості, стресостійкість, постійне прагнення до професійного росту і вдосконалення свого робочого продукту чи послуги [5]. Але, окрім вказаних якостей, важливою $\epsilon$ здатність устояти і бути переможцем у конкурентній боротьбі.

В. І. Шаповалов вважав, що до цих якостей належить інтелектуальний потенціал, здатність до самонавчання, адекватна самооцінка, інтернальність, відповідальні професійного комунікабельність, здатність приймати рішення, готовність до самовизначення, самоактуалізація та ін. Автором виділені п’ять компонентів конкурентоспроможності [15]:

1. Парадигмально-прогностичний (виявлення перспектив особистості до конкурентоспроможної поведінки);

2. Інформаційно-змістовий (комплекс знань пов'язаних із Я-концепцією, самооцінкою, прийняттям рішень та ін.);

3.Операційно-діяльністий (вміння i навики пізнавального, комунікативного, регулятивного характеру, які забезпечують успішність конкурентоспроможної поведінки);

4. Мотиваційно-ціннісний (цілісність особистості, бажання морального самовдосконалення, потреба в самоактуалізації, самоствердженні, саморозвитку); 


\section{Питання психології}

5. Емоційно-вольовий (відповідальність, самостійність, ініціативність, самоконтроль, впевненість у собі та ін.).

Відтак, конкурентоспроможність $\epsilon$ комплексом індивідуально-психологічних якостей особистості, які спонукають людину до самовдосконалення i саморозвитку в мінливому навколишньому середовищі, нестандартних життєвих умовах, здатністю знаходити гуманні способи досягнення власних цілей $\mathrm{i}$ бути успішних $\mathrm{y}$ професійному та особистому житті.

На ринку праці, як і в усіх сферах життєдіяльності існує конкуренція, тому потенційний працівник під час пошуку робочого місця повинен враховувати попит тієї чи іншої професії, особисті здібності та нахили, а також індивідуальні цілі. Враховуючи конкурентоспроможність особистості, саме в професійному плані, $є$ важливим ступінь оволодіння освітою, знаннями та навичками, які $є$ характерними для обраної професії. Але пріоритетними $є$ психофізіологічні та соціального-психічні особливості особистості. Окрім усіх цих чинників, важливим $є$ ступінь задоволення працівника своєю роботою, оскільки від цього залежить трудова дисципліна, результативність та якість праці, бажання розвиватися на особистісне i організаційне благо. Таким чином конкурентоспроможний працівник - це професіонал, який володіє конкурентними перевагами i здатен задовільнити потреби організації, враховуючи особисті потреби в самореалізації та самоактуалізації [14].

В управлінні персоналом організації важливо враховувати усі ці чинники для забезпечення підприємства саме типи працівниками, які мають характерні особливості для обраної професії. Керівникам варто об'єктивно оцінювати професійну придатність працівника, що у свою чергу дозволить активізувати наявні знання та навички фахівця, реалізувати особистий потенціал і стрімко розвивати необхідні компетенції. Важливо забезпечити організацію такими працівниками, які спроможні реалізувати основну мету підприємства, маючи для цього необхідні здібності та компетенції, а також потенціал для постійного розвитку [6].

Водночас високий рівень професіоналізму на стадіях професійної майстерності та наставництва супроводжується досягненням таких особистісних характеристик, як критичність, упевненість у собі, незалежність суджень, підвищений рівень домагань, висока потреба у визнанні, креативність, внутрішній локус контролю, високий рівень рефлексії, соціальної відповідальності. Такі індивідуально-психологічні характеристики притаманні конкурентоспроможним особам, але, при цьому, їхня гіперболізація та завищена самооцінка можуть провокувати міжособистісні конфлікти професіоналів 3 керівниками, іншими працівниками, що може негативно впливати на конкурентоспроможність фахівця [8].

Для працівника фінансово-кредитної організації аби бути конкурентоспроможним потрібно відповідально ставитись до своїй роботи, виконувати іiі якісно i точно. Особливе значення в роботі банку має глибина професійних знань, досвід роботи, розуміння своїх сильних та слабких сторін, прагнення та орієнтація на успіх, витримка, здатність зосередитись i продуктивно працювати в напружених i стресових ситуаціях, висока працездатність.

У переліку професійно-важливих якостей працівника фінансово-кредитних організацій безсумнівно $\epsilon$ компоненти емоційного інтелекту, тому він виступає важливим чинником конкурентоспроможності. У зв'язку 3 цим набула розвитку концепція емоційного та соціального інтелекту. Відносно існуючих дослідницьких підходів спробуємо визначити, що мається на увазі під поняттям «емоційний інтелект».

$\mathrm{X}$. Гардер у своїй теорії різноманітних інтелектів виділяв внутрішньоособистісний і міжособистісний інтелект, що теж має відношення до емоційного інтелекту, так як внутрішноособистісний інтелект, на думку автора, це доступ до свого емоційного життя і афектів, вміння розпізнавати власні почуття, давати їм ім'я, переводити у специфічні коди і 


\section{Питання психології}

використовувати для управління власною поведінкою [1].

Уперше термін «емоційний інтелект» у психологію ввели Дж. Мейєр і П. Селовей, які вважали, що це здатність сприймати, виражати, розуміти, пояснювати, регулювати власні емоції та інших людей. Спершу дослідники вважали, що емоційний інтелект $є$ складним за своєю конструкцією і має в собі три складові:

1. Ідентифікація і вираження емоцій;

2. Регуляція емоцій;

3. Використання інформації про емоції у мисленні і діяльності.

Перша i друга складова поділяється за спрямованістю на власні та чужі емоції, що можуть сприйматися вербально, невербально та за допомогою емпатії. Щодо третьої складової, то вона відображається у глибокому плануванні, творчому мисленні, перенаправленні уваги і мотивації та ін. [3].

Згодом Дж. Мейєр i П. Селовей доопрацювати i уточнили дану модель. Автори говорили, що емоції містять у собі інформацію про зв'язки людини 3 іншими людьми чи предметами, тобто вони «інформують» людину про характер цих зв'язків, при цьому вони можуть бути не лише актуальними, але й тими що є у пам'яті або уявними. Відповідно до цього, емоційний інтелект - це здатність переробляти інформацію, яка $\epsilon$ в емоціях - визначати значення емоцій, їх зв'язок 3 іншими емоціями, використовувати інформацію про емоції в якості основи для мислення i прийняття рішень.

Таким чином, було виділено чотири компоненти емоційного інтелекту [4]:

1. Ідентифікація емоцій, що включає в себе здатність сприймати емоції (помітити емоцію), адекватне вираження, розрізнення справжніх та імітованих емоцій;

2. Використання емоцій для підвищення ефективності мислення i діяльності, тобто здатність використовувати емоції аби спрямувати увагу на важливі події та викликати емоції, які необхідні для вирішення певної задачі чи проблеми, а також використовувати коливання настрою для аналізу різних точок на проблему.
3. Розуміння емоцій - це розуміння зв'язків між емоціями, переходи 3 однієї емоції на іншу, вербальну інформацію про емоції, причини виникнення певних емоційних станів. Здатність до розуміння емоції означає, що людина може становити факт наявності емоції, диференціювати іiі серед інших, тобто встановити, яку саме емоцію відчуває вона чи інший і вербально висловлювати іiі. Важливо розуміти причину виникнення цієї емоції та які наслідки будуть цьому слідувати;

4. Управління емоціями, що виражається у контролі інтенсивності емоціі, зниженні сили негативних емоцій, здатності до вирішення емоційно насичених проблем без ïх уникання i заперечення, контроль зовнішнього вираження. Це сприяє особистісному зростанню i покращенню міжособистісних стосунків.

Д. Гоулмен доповнив цю модель такими компонентами, як ентузіазм, наполегливість i соціальні навики, тим самим до когнітивних здібностей, які виділяли Дж. Мейєр і П. Селовей додав особистісні характеристики [7].

Савєнков A.I. виділив когнітивні, емоційні та поведінкові критерії, які описують концепцію соціального інтелекту. До когнітивних належить соціальні знання (знання правил спілкування, розуміння співрозмовника), соціальна пам'ять (імена, обличчя), соціальна інтуїція (визначення емоційних реакцій, причин вчинків інших людей), соціальне прогнозування (планування своїх вчинків, аналіз потенційних можливостей i напрямку розвитку). До емоційних компонентів належить емоційне сприйняття, співчуття та здатність до регуляції своїх емоційних станів. До поведінкових - соціальне сприйняття (вміння слухати співрозмовника), соціальна взаємодія (вміння працювати 3 іншими, бути членом згуртованої команди), соціальна адаптація (вміння переконувати інших, ефективно будувати стосунки 3 людьми) [13].

Особистість 3 високий рівнем емоційного інтелекту здатна встановлювати якісні міжособистісні зв'язки, наділена комунікативними якостями, так як розуміє 


\section{Питання психології}

власні та чужі емоції, а також уміло управляє ними.

Варто зазначити, що переживання емоції i iii визначення $\epsilon$ різними процесами, так як визначення певної емоції розглядається як результат конструктивних процесів, які трансформують перцептивні переживання у внутрішній досвід. Відповідно до цього функціями емоційного інтелекту $\epsilon$ закріплення досвіду, міжособистісна комунікація та емоційна експресія.

Адекватне вираження емоції $\epsilon$ важливим для підтримки фізичного та емоційного здоров'я, тому що постійне та тривале стримування афективних реакцій може призводити до виникнення різноманітних соматичних захворювань. Але неконтрольованість власних реакцій, надмірне вираження емоцій у певних обставинах негативно впливає на побудову стосунків 3 іншими людьми. Відтак потрібно розуміти, яким чином та в який момент виражати свою експресивність так, аби не здаватися іншим надто «холодним» та байдужим чи неконтрольованим та надмірно емоційним.

Розуміння емоцій тісно пов'язане із емпатичними здібностями, що характеризуються чутливістю до переживань іншої людини шляхом ототожнення себе 3 нею. Емпатія включає в себе постійну чутливість до мінливих переживань партнера по спілкуванню. Виявляється емпатійність у терпеливому ставленні до емоцій іншої людини, бажанні пізнати внутрішній світ співрозмовника, готовність адаптувати своє сприйняття до сприйняття ситуації іншої людини, бажання допомогти іншому. I на противагу цьому, особа, у якої відсутні емпатичні здібності або розвинені на низькому рівні, характеризується байдужістю, не здатніою співпереживати та розуміти емоційні та нелогічні вчинки інших [9].

Здатність відчувати та сприймати емоції та почуття іншої людини як власні та вміння надавати емоційний зворотній зв'язок $\epsilon$ важливими для професій, які передбачають спілкування 3 людьми, зокрема працівників банківських установ.
Емоційний інтелект працівників $\epsilon$ важливим для діяльності підприємства, яке надає послуги людям, тому можна виділити так звану «емоційно інтелектуальну організацію». Для неї характерний високий рівень емоційного інтелекту більшості працівників, формальних та неформальних лідерів, високий рівень управлінської етики, успішне антикризове управління, здатність персоналу до здорової конкуренції.

Так як робота у сфері «людина-людина» передбачає конфліктні ситуації, то надважливою здатністю емоційного інтелекту $\epsilon$ контроль власних емоцій, так як він передбачає вміння контролювати деструктивні емоції, гнучкість, чесність та надійність у спілкуванні, вміння йти на компроміс, бажання вдосконалюватися заради надання якісних послуг.

У діяльності емоційний інтелект проявляється у таких компетенціях: емоційна усвідомленість, асертивність, емпатійність, контроль афективності та агресивності, незалежність та відповідальність у соціальних проявах, стійкість у стресових ситуаціях, добре тестування реальності, вміння налагоджувати здорові міжособистісні стосунки, повага до себе, прагнення до самоактуалізації та щастя.

Через те кожен із керівників хотів би мати у своїй організації працівників, саме із такими компетенціями, тобто із високим рівнем емоційного інтелекту, що у свою чергу позитивно впливає на ефективність і якісні показники результативності організації в цілому.

Аналіз існуючих досліджень показав, що конкурентоспроможність особистості, успішність ії професійної діяльності має тісний зв'язок із рівнем розвитку емоційного інтелекту, який набуває особливої значущості, так як професійно важливі якості працівника фінансово-кредитної установи $є$ основними компонентами емоційного інтелекту.

Висновки. Велика кількість банківських установ на споживчому ринку вимагає від банкірів використовувати і вдосконалювати усі можливі ресурси. Одним із таких ресурсів $\epsilon$ людина, як основний інструмент здійснення діяльності банківських установ. На 


\section{Питання психології}

ефективність роботи працівників організації мають вплив різного виду мотивації (фінансові, соціальні та психологічні), що створює конкурентне середовище, при якому фахівцю необхідно мати не лише спеціалізовану освіту та досвід роботи, але й володіти необхідними професійними i особистісними якостями.

Так як робота працівника банківської установи передбачає постійне спілкування із різноманітними клієнтами, важливим є рівень розвитку емоційного інтелекту фахівця, який виражається у розумінні власних емоцій та емоцій клієнтів, здатністю контролювати і управляти емоційними станами, навики емпатії, відкритість та гнучкість у спілкуванні.

Таким чином, емоційний інтелект $\epsilon$ чинником конкурентоспроможності. При цьому варто зазначити, що здорове конкурентне середовище сприяе саморозвитку і самоактуалізації особистості та ефективній діяльності установи в цілому.

\section{Список використаних джерел}

1. Gardner, H. Frames of mind: The theory of multiple intelligences, New York: Basic Books, 2011. pp. $77-292$.

2. Guilford J.P. The nature of human intelligence. New York: McGraw"Hill, 1967.

3. Mayer J.D., Caruso D.R., Salovey P. Emotional Intelligence meets traditional standards for an intelligence. Intelligence. 1999. V. 27. P. 267-298.

4. Mayer J.D., Salovey P., Caruso D.R., Sitarenios G. Emotional intelligence as a standard intelligence. Emotion. 2001. V. 1. P. 232-242.

5. Андреев, В.И. Конкурентология. Учебный курс для творческого саморазвития конкурентоспособности. Казань: Центр инновационных технологий, 2013. -468 с.

6. Гаврилюк I. В. Розвиток персоналу як фактор конкурентоспроможності працівників та організаціï. Економіка. Управління. Інновації? 2009. № 2. URL: http://nbuv.gov.ua/UJRN/eui_2009_2_10. (дата звернення: 24.08 2020).

7. Гоулман Д. Эмоциональный интеллект. Почему он может значить больше, чем IQ (пер. с англ. А. П. Исаевой). 6-е изд. М. : Манн, Иванов и Фербер, 2018. - 560 с.

8. Климчук А. О. Вилив факторів на формування та підвищення конкурентоспроможності персоналу підприємства. Науковий вісник Ужгородського національного університету: серія: Міжнародні економічні відносини та світове господарство/ голов. ред. М.М. Палінчак. Ужгород: Видавничий дім «Гельветика», 2016. Вип. 7, Ч. 2. - С. 6-9.

9. Мельничук О. Б. Емпатія в структурі професійного інтелекту майбутніх фахівиів соціальної сфери. Проблеми сучасної психології. 2016. Вип. 31. URL: http://nbuv.gov.ua/UJRN/Pspl 2016_31_19 (дата звернення: 23.07 2020).

10. Митина Л.М. Психология развития конкурентоспособной личности. М.: Изд-во Московский психолого-социальный институг; Воронеж: Изд-во НПО «Модэк», 2003. 400 с.

11. Подосинников С.А. Психология конкурентоспособности профессионала. Астрахань: Астраханский ун-т, 2008. С. 127-130.

12. Психологічні аспекти професійної підготовки конкурентоздатних фахівиів: монографія / Дегтярьова Г.С., Козяр М.М., Матійків І.М., Руденко Л.А., Шиделко А.В.; за ред. Руденко Л.А.. Київ, 2012. $170 \mathrm{c}$.

13. Савенков А.И. Структура соииального интеллекта. Современная зарубежная психология. 2018. Том 7. № 2. С. 7-15.

14. Церковский, А.Л. Современные взгляды на проблему конкурентоспособности. Вестн. ВГМУ. 2016. Т. 15, № 1. - С. 114-127.

15. Шаповалов В.И. Формирование конкурентоспособной личности в условиях школьного дополнительного образования: Моногр. Под науч. ред. Ю.С. Тюнникова. -Сочи: СГУТиКД, 2008. -190 с.

\section{References}

1. Gardner, H. Frames of mind: The theory of multiple intelligences, New York: Basic Books, 2011. pp. $77-292$.

2. Guilford J.P. The nature of human intelligence. New York: McGraw"Hill, 1967. 


\section{Питання психології}

3. Mayer J.D., Caruso D.R., Salovey P. Emotional Intelligence meets traditional standards for an intelligence. Intelligence. 1999. V. 27. P. 267-298.

4. Mayer J.D., Salovey P., Caruso D.R., Sitarenios G. Emotional intelligence as a standard intelligence. Emotion. 2001. V. 1. P. 232-242.

5. Andreev V.I. (2013). Konkurentologija. Uchebnyj kurs dlja tvorcheskogo samorazvitija konkurentosposobnosti [Competitiveness. Training course for creative self-development of competitiveness]. Kazan: Centr innovacionnyh tehnologij (in Russian).

6. Havryliuk I. V. (2009) Rozvytok personalu yak faktor konkurentospromozhnosti pratsivnykiv ta orhanizatsii [Personnel development as a factor of competitiveness of work and organization]. Economy. Management. Innovations Retrieved from: http://nbuv.gov.ua/UJRN/eui_2009_2_10 (in Ukrainian).

7. Goulman D. (2018) Jemocional'nyj intellekt. Pochemu on mozhet znachit' bol'she, chem IQ [Emotional intelligence. Why he can know more than IQJ Mann, Ivanov and Ferber (in Russian).

8. Klymchuk A. O. (2016) Vplyv faktoriv na formuvannia ta pidvyshchennia konkurentospromozhnosti personalu pidpryiemstva [Influence of factors on formation and increase of competitiveness of the personnel of the enterprise] Uzhhorod: Vidavnichij dim «Gel'vetika» [in Ukrainian].

9. Melnychuk O. B. (2016) Empatiia v strukturi profesiinoho intelektu maibutnikh fakhivtsiv sotsialnoi sfery [Empathy in the structure of professional intelligence of future professionals in the social sphere] Problems of modern psychology Retrieved from: http://nbuv.gov.ua/UJRN/Pspl_2016_31_19 [in Ukrainian].

10. Mitina L.M. (2003) Psihologija razvitija konkurentosposobnoj lichnosti [Psychology of the development of a competitive personality] Voronezh: NPO «Modjek» (in Russian).

11. Podosinnikov S.A. (2008) Psihologija konkurentosposobnosti professional [Definition of competitiveness as a psychological phenomenon] Astrakhan: Astrahanskij un-t (in Russian).

12. Dehtiarova H.S., Koziar M.M., Matiikiv I.M., Rudenko L.A., Shydelko A.V (2012) Psykholohichni aspekty profesiinoi pidhotovky konkurentozdatnykh fakhivtsiv: monohrafiia [Psychological aspects of professional training of competitive specialists] Kiev (in Russian).

13. Savenkov A.I. (2018) Struktura social'nogo intellekta [The structure of social intelligence] Contemporary foreign psychology (in Russian).

14. Cerkovskij, A.L. (2016) Sovremennye vzgljady na problemu konkurentosposobnosti [Modern views on the problem of competitiveness] Vestn. VGMU (in Russian).

15. Shapovalov V.I. (2008) Formirovanie konkurentosposobnoj lichnosti v uslovijah shkol'nogo dopolnitel'nogo obrazovanija /Formation of a competitive personality in the context of additional school education] Sochi: SGUTiKD (in Russian).

\section{Резюме \\ Остафийчук $\boldsymbol{P}$. Ю. аспирант, НУ «Львовская политехника» \\ ЭМОЦИОНАЛЬНЫЙ ИНТЕЛЛЕКТ КАК ФАКТОР КОНКУРЕНТОСПОСОБНОСТИ РАБОТНИКОВ БАНКОВСКИХ УЧРЕЖДЕНИЙ}

В статье осуществлен теоретический анализ основных подходов $к$ изучению понятия конкурентоспособности. Рассмотрень понятия эмоиионального интеллекта и его влияние на конкурентоспособности работника финансово-кредитного учреждения. Определены факторы, которые оказывают влияние на конкурентоспособность работников. Обоснована необходимость интереса руководства в создании здоровых конкурентных отномений между работниками, так как это обеспечивает эффективность деятельности персонала и успешность организации.

Ключевые слова: конкуренция; конкурентоспособность; эмочиональный интеллект; социальный интеллект; эмпатия.

\section{Summary \\ Ostafiichuk R. Y. Graduate student, assistant of the National Lviv Polytechnic University \\ EMOTIONAL INTELLIGENCE AS A FACTOR OF COMPETITIVENESS OF BANKING INSTITUTIONS}

Introduction. The article provides a theoretical analysis of the main approaches to the study of the concept of competitiveness. The concepts of emotional intelligence and its influence on the competitiveness of the employee of a financial institution are considered. Factors that affect the competitiveness of employees have been identified. 


\section{Питання психології}

The need for management's interest in creating a healthy competitive relationship between employees is justified, as it ensures the efficiency of staff and the success of the organization.

Purpose. Theoretical analysis of the problem of emotional intelligence as a factor in the competitiveness of employees of a banking institution.

Methods. The study of emotional intelligence as a factor in the competitiveness of employees of a banking institution is possible through the synthesis of scientific approaches that complement the concept of competition, factors of competitiveness, including emotional intelligence, its impact on employee well-being and organization.

Originality. Given the number of existing financial and credit institutions in the consumer market, bankers face a problem: to organize the work of their enterprise so as to be more competitive. This is manifested in the volume and quality of banking services, modernization and optimization of work, attracting external and retaining existing customers, etc.

The level of staff development is important for the effective functioning of an organization that works with people. Therefore, the modern enterprise must attach great importance to the problems of selection of candidates for the vacant position, and subsequently the management and staff development.

Being competitive with an employee means gaining career growth, getting better pay and motivation, being recognized by colleagues and the bank's management, and being more useful to the organization. Therefore, it is necessary to create a competitive environment for employees, where everyone would have the opportunity to realize their potential for a positive personal result and the success of the banking institution as a whole.

Today the concept of competition and competitiveness is studied, the basic psychological strategies of competition in the organizations are defined, the problem of competitiveness of the person is investigated. Less studied is emotional intelligence as a factor in the competitiveness of employees of the organization, in particular financial and credit.

Conclusion. Given the theoretical analysis of the chosen topic, it is determined that emotional intelligence is a factor in competitiveness. It should be noted that a healthy competitive environment promotes self-development and self-actualization of the individual and the effective operation of the institution as a whole.

Key words. competition; competitiveness; emotional intelligence; social intelligence; empathy.

Recelved/Поступила: 03.12.20. 